\title{
Diffusion Research in BCC Ti-Al-Zr Ternary Alloys
}

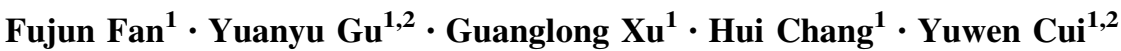

Submitted: 1 June 2019/in revised form: 25 August 2019/Published online: 23 September 2019

(c) ASM International 2019

\begin{abstract}
Diffusion behavior in the BCC Ti-Al-Zr ternary alloys was experimentally investigated at $1273 \mathrm{~K}$ $\left(1000{ }^{\circ} \mathrm{C}\right)$ and $1473 \mathrm{~K}\left(1200{ }^{\circ} \mathrm{C}\right)$ by means of the diffusion-couple technique. Upon the Whittle-Green and generalized Hall methods, the inter- and impurity diffusion coefficients were respectively extracted from the composition profiles acquired by the electron microprobe analysis (EPMA) and subsequently represented by the error function expansion. The extracted main interdiffusion coefficient $\tilde{D}_{\mathrm{AlAl}}^{\mathrm{Ti}}$ increases with increasing the content of either $\mathrm{Al}$ or $\mathrm{Zr}$, and the increase is appearing more considerably at the higher temperature. However, $\tilde{D}_{\mathrm{ZrZr}}^{\mathrm{Ti}}$ was noticed to decrease with the increase of $\mathrm{Al}$ and $\mathrm{Zr}$ contents at $1273 \mathrm{~K}$ $\left(1000{ }^{\circ} \mathrm{C}\right)$ while there is an upward trend at $1473 \mathrm{~K}$ $\left(1200{ }^{\circ} \mathrm{C}\right)$. The impurity diffusion coefficients of $\mathrm{Al}$ in Ti$\mathrm{Zr}$ binary alloys, $D_{\mathrm{Al}(\mathrm{Ti}-\mathrm{Zr})}^{*}$, and of $\mathrm{Zr}$ in Ti-Al binary alloys, $D_{\mathrm{Zr}(\mathrm{Ti}-\mathrm{Al})}^{*}$, increase with increasing the $\mathrm{Zr}$ and $\mathrm{Al}$ contents respectively. A comparison of average main interdiffusion coefficient $\overline{\tilde{D}_{\mathrm{XX}}^{\mathrm{Ti}}}$ made among ten Ti-Al-X ternary systems suggests that the $\mathrm{Zr}$ diffusion is most comparable to $\mathrm{Cr}$ and could operate via a vacancy-controlled mechanism.
\end{abstract}

Fujun Fan and Yuanyu Gu have contributed equally to this work.

Yuwen Cui

ycui@unizar.es

1 Tech Institute for Advanced Materials and School of Materials Science and Engineering, Nanjing Tech University, Nanjing 210009, People's Republic of China

2 Instituto de Ciencia de Materiales de Aragon (ICMA), Zaragoza 50009, Spain
Keywords generalized Hall method - impurity diffusion · interdiffusion - Ti-Al-Zr BCC ternary alloys · WhittleGreen method

\section{Introduction}

Titanium and its alloys have increasing applications in aerospace, automotive and marine industries due to their high specific strength, excellent mechanical properties and good corrosion resistance. ${ }^{[1-3]}$ Most commercial titanium alloys are complex and multicomponent in nature. Representative $\mathrm{Ti}$ alloys include Ti-6321, ${ }^{[4]} \mathrm{Ti}-7333,{ }^{[5]} \mathrm{Ti}-$ $55531,{ }^{[6]}$ and Ti-B $19,{ }^{[7]}$ etc., which are principally alloyed with elements classified as $\alpha$ (HCP), $\beta$ (BCC), or neutral stabilizers. The $\alpha$ stabilizing element Al practically enhances the tensile and the creep strength while it reduces the density, whereas the neutral element $\mathrm{Zr}$ is typically used as solidsolution strengthener to improve corrosion resistance, processability, and weldability. ${ }^{[8,9]}$ The knowledge-driven optimization of the mechanical properties of complex titanium alloys are essentially the control of intricate microstructures through such processes and transformations as recovery, recrystallization, grain growth, and precipitation, all of which are more or less governed by the diffusion phenomena. In fact, accurate diffusion properties also serve as the fundamental kinetic data for mesoscale modeling of microstructural evolution ${ }^{[10]}$ and macroscale modeling of solidification process. ${ }^{[11]}$

So far, the diffusion properties of BCC Ti-Al ${ }^{[12,13]}$ and $\mathrm{Ti}^{-} \mathrm{Zr}^{[14]}$ binary alloys have received attention, however, the diffusion in BCC Ti-Al-Zr ternary alloys has been yet addressed. Therefore, the objectives of the present work are to investigate the interdiffusion behaviors of $\mathrm{BCC} \mathrm{Ti}-\mathrm{Al}-\mathrm{Zr}$ 
ternary alloys at $1273 \mathrm{~K}\left(1000{ }^{\circ} \mathrm{C}\right)$ and $1473 \mathrm{~K}\left(1200{ }^{\circ} \mathrm{C}\right)$, and to extract the inter- and impurity ternary diffusion coefficients, respectively.

\section{Materials and Methods}

\subsection{Experimental Procedure}

Fourteen binary and six ternary alloys were prepared from 99.9 wt.\% sponge pure Ti, 99.99 wt.\% $\mathrm{Al}$ and 99.9 wt.\% $\mathrm{Zr}$ pure granules by induction melting under an argon atmosphere. The actual compositions of the alloys are listed in Table 1. All the compositions of the alloys were designed to locate in the $\mathrm{BCC}$ phase region of $\mathrm{Ti}-\mathrm{Al}-\mathrm{Zr}$ system at both $1273 \mathrm{~K}\left(1000{ }^{\circ} \mathrm{C}\right)$ and $1473 \mathrm{~K}\left(1200{ }^{\circ} \mathrm{C}\right)$ according to the accepted phase diagrams. ${ }^{[15]}$ The melting was repeated six times to attain a homogeneous composition.

The alloy ingots were then solid-solution treated under vacuum in quartz tubes at $1473 \mathrm{~K}\left(120{ }^{\circ} \mathrm{C}\right)$ for $10 \mathrm{~h}$ followed by water quenching, which resulted in the alloys with average grain size larger than $1 \mathrm{~mm}$ such that the effect of grain boundary diffusion could be neglected. Small rectangular blocks with a size $9 \times 9 \times 5 \mathrm{~mm}$ were cut from the annealed ingots. One of the wide surfaces of the blocks were polished to mirror-like quality. The wellcontacted diffusion couples were assembled with appropriate pairs by diffusion-bonding under vacuum $\left(10^{-3} \mathrm{~Pa}\right)$ at $1173 \mathrm{~K}\left(900{ }^{\circ} \mathrm{C}\right)$ for $4 \mathrm{~h}$ by using a stainless steel bonding jig, during which tantalum foil was placed between the couple and the jig to avoid the contamination. The assembled diffusion couples were then capsuled into quartz tubes, evacuated and back-flashed with argon, annealed under predetermined conditions (refer to Table 1 for the temperatures and times of long-term interdiffusion annealing), and quenched into cold water. The diffusion couples were sectioned along the diffusion direction which suffered no potential oxidation and evaporation of elements, and prepared by standard metallographic technique. The microstructures of diffusion zone of the diffusion couples were characterized by scanning electron microscopy (SEM) and the local compositions along the diffusion direction were analyzed by electron microprobe analysis (EPMA, JEOL JAX-8230).

\subsection{Extraction of Diffusion coefficients}

Figure 1 presents the backscattered electron (BSE) image of diffusion couple A7 at $1273 \mathrm{~K}\left(1000{ }^{\circ} \mathrm{C}\right)$ for $48 \mathrm{~h}$ and the composition profiles of $\mathrm{Al}$ and $\mathrm{Zr}$ obtained by the EPMA measurements. To avoid the point-to-point fluctuation of the experimental data and the errors introduced during the fitting or smoothing, the error function expansion $(\mathrm{ERFEX})^{[16-19]}$ was used to represent the composition profiles acquired by EPMA with analytical form:
Table 1 Actual terminal compositions of $\mathrm{Ti}-\mathrm{Al}-\mathrm{Zr}$ diffusion couples (at.\%)

\begin{tabular}{|c|c|c|c|}
\hline Temperature, $\mathrm{K}$ & Diffusion time, $\mathrm{h}$ & Diffusion couples & Compositions, at.\% \\
\hline \multirow[t]{9}{*}{1273} & 48 & A1 & $\mathrm{Ti}-1 \mathrm{Al} / \mathrm{Ti}-4.4 \mathrm{Zr}$ \\
\hline & & $\mathrm{A} 2$ & $\mathrm{Ti}-2.8 \mathrm{Al} / \mathrm{Ti}-4.3 \mathrm{Zr}$ \\
\hline & & A3 & $\mathrm{Ti}-2.8 \mathrm{Al} / \mathrm{Ti}-9.9 \mathrm{Zr}$ \\
\hline & & A4 & $\mathrm{Ti}-5.1 \mathrm{Al} / \mathrm{Ti}-13.5 \mathrm{Zr}$ \\
\hline & & A5 & $\mathrm{Ti}-5.5 \mathrm{Al} / \mathrm{Ti}-19.9 \mathrm{Zr}$ \\
\hline & & A6 & $\mathrm{Ti}-5.5 \mathrm{Al} / \mathrm{Ti}-28.2 \mathrm{Zr}$ \\
\hline & & A7 & $\mathrm{Ti} / \mathrm{Ti}-9.5 \mathrm{Al}-39.5 \mathrm{Zr}$ \\
\hline & & A8 & $\mathrm{Ti} / \mathrm{Ti}-11.2 \mathrm{Al}-20.1 \mathrm{Zr}$ \\
\hline & & A9 & $\mathrm{Ti}-2.8 \mathrm{Al} / \mathrm{Ti}-11.6 \mathrm{Al}-19.6 \mathrm{Zr}$ \\
\hline \multirow[t]{11}{*}{1473} & 17 & B1 & $\mathrm{Ti}-2.6 \mathrm{Al} / \mathrm{Ti}-4.3 \mathrm{Zr}$ \\
\hline & & B2 & $\mathrm{Ti}-5.2 \mathrm{Al} / \mathrm{Ti}-4.4 \mathrm{Zr}$ \\
\hline & & B3 & $\mathrm{Ti}-5.2 \mathrm{Al} / \mathrm{Ti}-8.7 \mathrm{Zr}$ \\
\hline & & B4 & $\mathrm{Ti}-8.8 \mathrm{Al} / \mathrm{Ti}-12.9 \mathrm{Zr}$ \\
\hline & & B5 & $\mathrm{Ti}-14.2 \mathrm{Al} / \mathrm{Ti}-19.9 \mathrm{Zr}$ \\
\hline & & B6 & $\mathrm{Ti}-19.5 \mathrm{Al} / \mathrm{Ti}-28.7 \mathrm{Zr}$ \\
\hline & & B7 & $\mathrm{Ti}-14.8 \mathrm{Al} / \mathrm{Ti}-38.4 \mathrm{Zr}$ \\
\hline & & B8 & $\mathrm{Ti}-19.5 \mathrm{Al} / \mathrm{Ti}-38.4 \mathrm{Zr}$ \\
\hline & & B9 & $\mathrm{Ti} / \mathrm{Ti}-9.7 \mathrm{Al}-36.3 \mathrm{Zr}$ \\
\hline & & $\mathrm{B} 10$ & $\mathrm{Ti} / \mathrm{Ti}-12.3 \mathrm{Al}-19.2 \mathrm{Zr}$ \\
\hline & & B11 & $\mathrm{Ti} / \mathrm{Ti}-14.5 \mathrm{Al}-11.4 \mathrm{Zr}$ \\
\hline
\end{tabular}




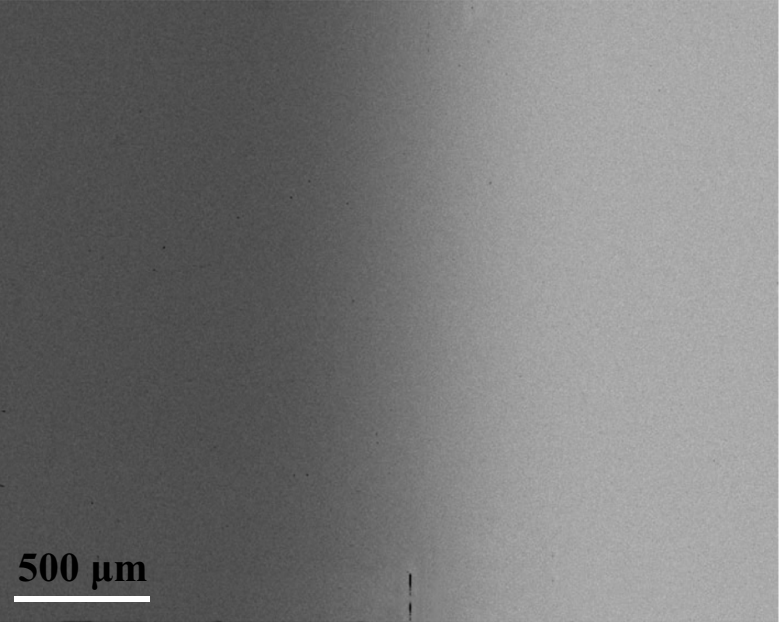

(a)

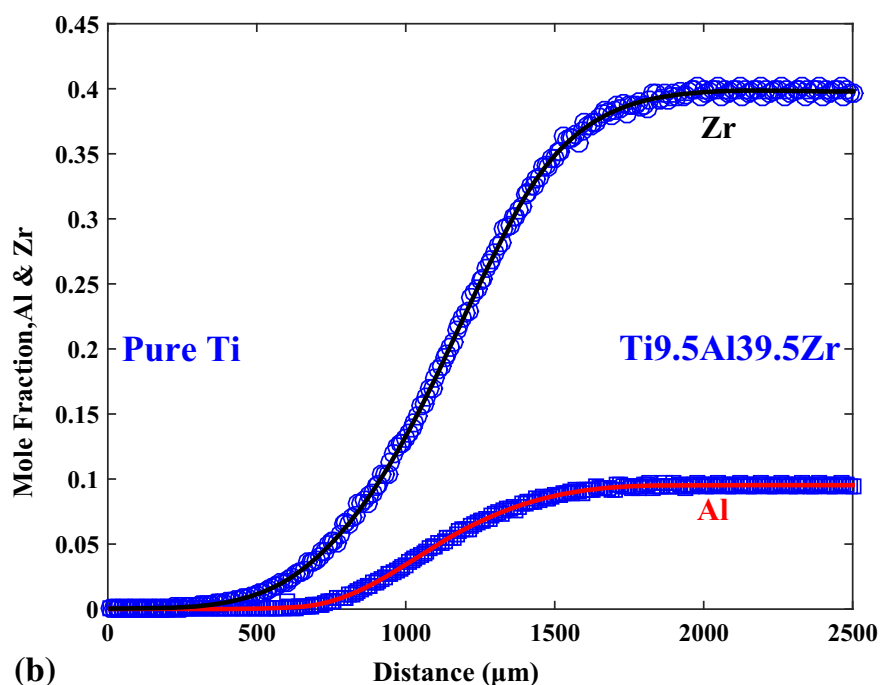

(b)

Fig. 1 Cross-sectional BSE micrograph (a) and composition profiles (b) of diffusion couple A7 at $1273 \mathrm{~K}$ for $48 \mathrm{~h}$. The symbols are EPMA measurements

$x(z)=\sum_{i} a_{i} \operatorname{erf}\left[b_{i} z-c_{i}\right]$,

where $x(z)$ represents the composition at the distance $z, a$, $b$, and $c$ are the adjustable parameters, and i is typically up to 4 depending on the details of composition profiles of the diffusion couple.

To avoid the need of locating the Matano plane in the well-known Matano-Kirkaldy method, ${ }^{[20]}$ that may introduce a source of some uncertainty, the Whittle-Green (W$\mathrm{G})^{[21]}$ method was utilized to extract ternary interdiffusion coefficients. The W-G method introduces a normalized composition variable: $Y=\frac{x-x_{L}}{x_{R}-x_{L}}$, where $x_{L}$ and $x_{R}$ represent the compositions at the left and right ends, respectively. ${ }^{[22]}$ For the Ti-Al-Zr ternary system, Fick's second law can be expressed with the W-G method as:

$$
\begin{aligned}
& \frac{1}{2 t}\left(\frac{\mathrm{d} z}{\mathrm{~d} Y_{\mathrm{Al}}}\right)_{z}\left[\left(1-Y_{\mathrm{Al}}\right) \int_{-\infty}^{z} Y_{\mathrm{Al}} \mathrm{d} z+Y_{\mathrm{Al}} \int_{z}^{+\infty}\left(1-Y_{\mathrm{Al}}\right) \mathrm{d} z\right] \\
& \quad=\tilde{D}_{\mathrm{AlAl}}^{\mathrm{Ti}}+\tilde{D}_{\mathrm{AlZr}}^{\mathrm{Ti}} \frac{\mathrm{d} x_{\mathrm{Zr}}}{\mathrm{d} x_{\mathrm{Al}}},
\end{aligned}
$$

$$
\begin{aligned}
& \frac{1}{2 t}\left(\frac{\mathrm{d} z}{\mathrm{~d} Y_{\mathrm{Zr}}}\right)_{z}\left[\left(1-Y_{\mathrm{Zr}}\right) \int_{-\infty}^{z} Y_{\mathrm{Zr}} \mathrm{d} z+Y_{\mathrm{Zr}} \int_{z}^{+\infty}\left(1-Y_{\mathrm{Zr}}\right) \mathrm{d} z\right] \\
& \quad=\tilde{D}_{\mathrm{ZrZr}}^{\mathrm{Ti}}+\tilde{D}_{\mathrm{ZrAl}}^{\mathrm{Ti}} \frac{\mathrm{d} x_{\mathrm{Al}}}{\mathrm{d} x_{\mathrm{Zr}}},
\end{aligned}
$$

where $\tilde{D}_{\mathrm{AlAl}}^{\mathrm{Ti}}$ and $\tilde{D}_{\mathrm{ZrZr}}^{\mathrm{Ti}}$ are the main interdiffusion coefficients, $\tilde{D}_{\mathrm{AlZr}}^{\mathrm{Ti}}$ and $\tilde{D}_{\mathrm{ZrAl}}^{\mathrm{Ti}}$ are the cross ones, respectively. All four interdiffusion coefficients can be obtained by simultaneously solving a set of four equations of Eq $2 \mathrm{a}$ and $2 \mathrm{~b}$ resulting from one pair of diffusion couples whose diffusion paths intersect at a common composition.
The impurity diffusion coefficients of $\mathrm{Al}$ in $\mathrm{BCC} \mathrm{Ti}-\mathrm{Zr}$ and $\mathrm{Zr}$ in $\mathrm{BCC} \mathrm{Ti}-\mathrm{Al}$ binary alloys were computed from composition profiles of the A1-A6 and B1-B6 couples by using the generalized Hall method. ${ }^{[23]}$ Similar to its binary protocol, the profiles were first transformed to a plot of $\mu$ versus $\lambda$, wherein $\mu=\operatorname{erf}^{-1}(2 Y-1)$ and $\lambda=x / \sqrt{t}$. By fitting the plot with a linearity $\mu=h \lambda+k$, the impurity diffusion coefficients on the left and right terminal compositions can be obtained by Eq $3 \mathrm{a}$ and $3 \mathrm{~b}$ respectively, with knowing the linear fit coefficients $h_{1}$ and $k_{1}$ for the left side, and $h_{2}$ and $k_{2}$ for the right side of the diffusion couples,

$$
\begin{aligned}
& \tilde{D}\left(x^{\prime}\right)=\frac{1}{4 h_{1}^{2}}\left[1+\frac{2 k_{1}}{\sqrt{\pi}} \exp \left(\mu^{2}\right) \times Y\left(x^{\prime}\right)\right], \\
& \tilde{D}\left(x^{\prime}\right)=\frac{1}{4 h_{2}^{2}}\left\{1-\frac{2 k_{2}}{\sqrt{\pi}} \exp \left(\mu^{2}\right)\left[1-Y\left(x^{\prime}\right)\right]\right\},
\end{aligned}
$$

where $x^{\prime}$ is the terminal composition.

\section{Experimental Results}

\subsection{Composition Profiles and Diffusion Paths}

Figure 2 shows two sets of the representative composition profiles of the diffusion couples fabricated in this work, i.e. the ternary couples A5 and A7 at $1273 \mathrm{~K}\left(1000{ }^{\circ} \mathrm{C}\right)$ for $48 \mathrm{~h}$ and the couples B2 and B9 at $1473 \mathrm{~K}\left(1200{ }^{\circ} \mathrm{C}\right)$ for $17 \mathrm{~h}$. It is apparent that the diffusion penetrations of $\mathrm{Al}$ and $\mathrm{Zr}$, in a typical S-shape, approximately range 1.5 and $2.0 \mathrm{~mm}$ (see Fig. 2a) at $1273 \mathrm{~K}\left(1000{ }^{\circ} \mathrm{C}\right)$, and 2.2 and $2.5 \mathrm{~mm}$ (see Fig. $2 \mathrm{~b})$ at $1473 \mathrm{~K}\left(1200^{\circ} \mathrm{C}\right)$, respectively. It thus implies that $\mathrm{Zr}$ diffuses in the BCC Ti-Al-Zr alloys at 
a rate faster that $\mathrm{Al}$ (i.e. being around 1.8 times), and the difference between $\mathrm{Al}$ and $\mathrm{Zr}$ decreases (from 1.8 to 1.2 times) when temperature rises.

Figure 3 maps the diffusion paths of the Ti-Al- $\mathrm{Zr}$ ternary couples at $1273 \mathrm{~K}\left(1000{ }^{\circ} \mathrm{C}\right)$ and $1473 \mathrm{~K}\left(1200{ }^{\circ} \mathrm{C}\right)$ in the ternary Gibbs' isotherms. The diffusion paths at both the temperatures are clearly S-shaped, however, their appearance differs at the two temperatures. At lower temperature of $1273 \mathrm{~K}\left(1000{ }^{\circ} \mathrm{C}\right)$, the ends of majority of the diffusion paths tend to be parallel to the direction at a constant $\mathrm{Al}$ content, i.e. the $\mathrm{Ti}-\mathrm{Zr}$ vicinity, concludes $\mathrm{Al}$ as a slower diffuser, ${ }^{[24]}$ while at higher temperature of $1473 \mathrm{~K}$

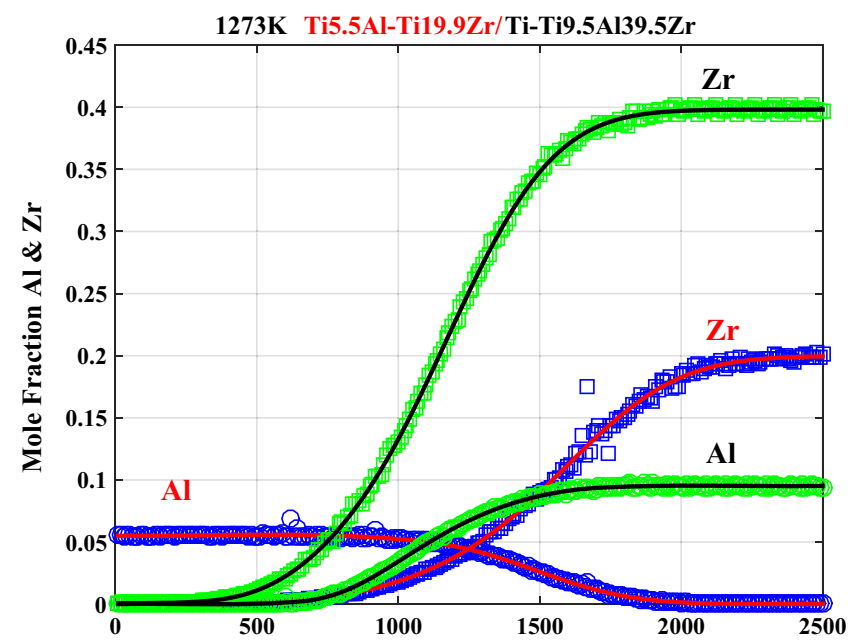

(a)

Distance $(\mu \mathrm{m})$

$\left(1200{ }^{\circ} \mathrm{C}\right)$, the end direction deviates, implying that $\mathrm{Zr}$ and $\mathrm{Al}$ tend to diffuse at the comparable rates.

\subsection{Diffusion Coefficients}

The interdiffusion coefficients extracted at the intersection compositions of the diffusion paths are summarized in Table 2 for $1273 \mathrm{~K}\left(1000{ }^{\circ} \mathrm{C}\right)$ and Table 4 for $1473 \mathrm{~K}$ $\left(1200{ }^{\circ} \mathrm{C}\right) .{ }^{[22,25]}$ Note that the standard deviations were determined from the independent calculations upon five ERFEX representation treatments with the EPMA data. The reliability of the obtained diffusion coefficients was

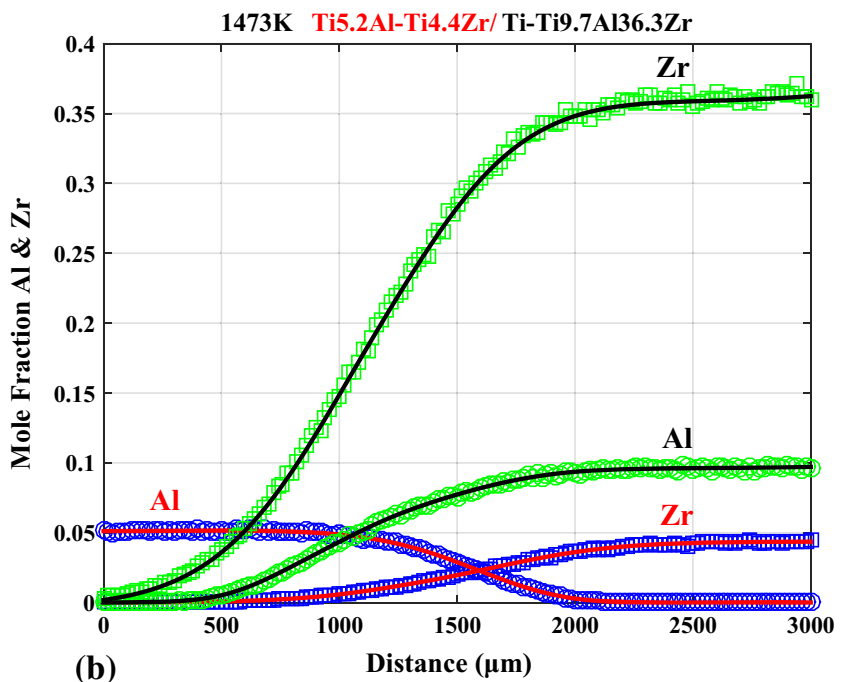

Fig. 2 Composition profiles of Ti-Al-Zr couples, (a) A5-A7 at $1273 \mathrm{~K}$ for 48 h, (b) B2-B9 at $1473 \mathrm{~K}$ for $17 \mathrm{~h}$. The symbols are EPMA data, and the curves are the analytical ERFEX forms

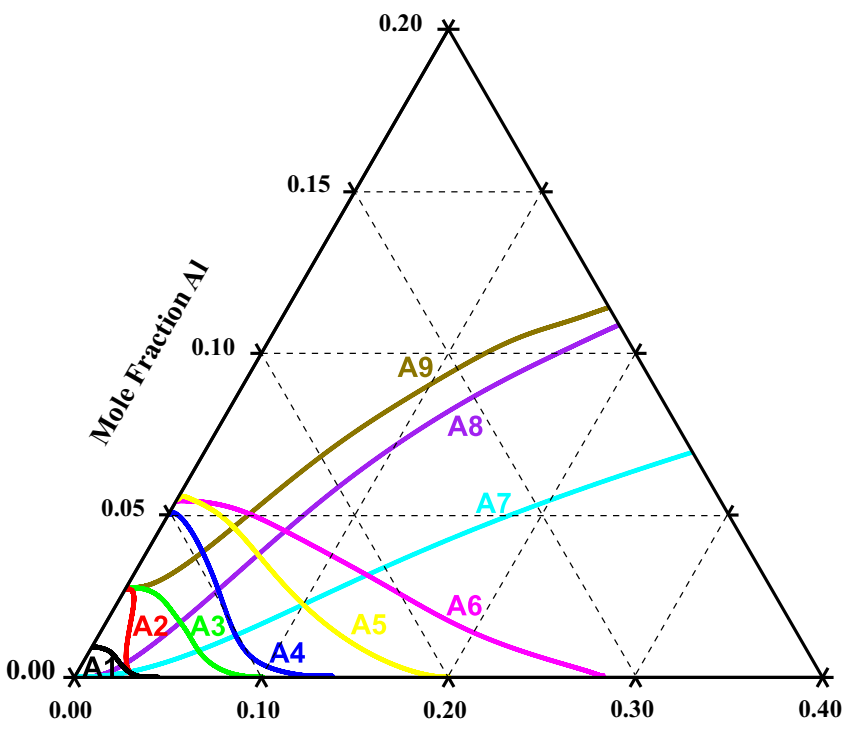

(a) $1273 \mathrm{~K}$

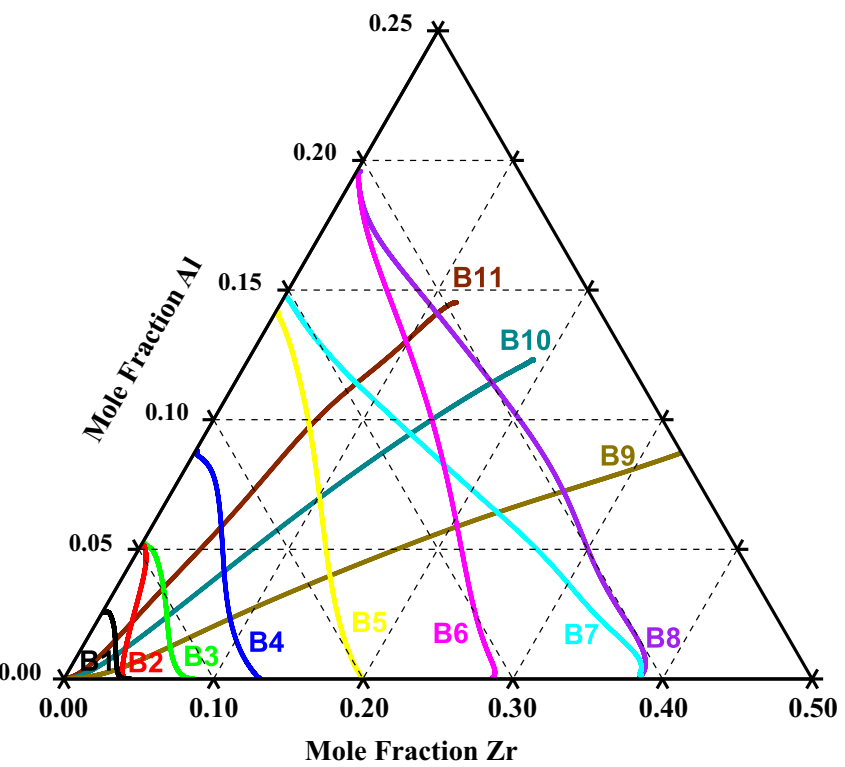

(b) $1473 \mathrm{~K}$

Fig. 3 Diffusion paths for Ti-Al-Zr couples annealed at (a) $1273 \mathrm{~K}$ for $48 \mathrm{~h}$, (b) $1473 \mathrm{~K}$ for $17 \mathrm{~h}$ 
Table 2 Experiment diffusion coefficients of BCC Ti-Al-Zr alloys at $1273 \mathrm{~K}\left(1000{ }^{\circ} \mathrm{C}\right)$
Table 3 Experiment diffusion coefficients of BCC Ti-Al-Zr alloys at $1473 \mathrm{~K}\left(1200{ }^{\circ} \mathrm{C}\right)$

\begin{tabular}{lccccccc}
\hline Diffusion couple & \multicolumn{2}{c}{ Composition, at.\% } & & \multicolumn{3}{c}{ Interdiffusion coefficients $\left(10^{-13} \mathrm{~m}^{2} \mathrm{~s}^{-1}\right)$} \\
\cline { 2 - 3 } \cline { 6 - 7 } & $\mathrm{Al}$ & $\mathrm{Zr}$ & & $\tilde{D}_{\text {AlAl }}^{T i}$ & $\tilde{D}_{\text {AlZr }}^{T i}$ & $\tilde{D}_{\mathrm{ZrZr}}^{T i}$ & $\tilde{D}_{\mathrm{ZrAl}}^{T i}$ \\
\hline A1-A7 & 0.2 & 2.8 & & $1.3 \pm 0.1$ & $0.02 \pm 0.1$ & $3.8 \pm 0.1$ & $-5.3 \pm 0.4$ \\
A1-A8 & 0.4 & 2.2 & & $1.1 \pm 0.1$ & $-0.1 \pm 0.1$ & $4.6 \pm 0.1$ & $-1.3 \pm 0.2$ \\
A2-A7 & 0.2 & 2.8 & & $1.3 \pm 0.1$ & $0.02 \pm 0.1$ & $3.6 \pm 0.1$ & $-4.0 \pm 0.4$ \\
A2-A8 & 0.4 & 2.3 & & $1.2 \pm 0.1$ & $-0.1 \pm 0.1$ & $4.6 \pm 0.1$ & $-0.9 \pm 0.1$ \\
A3-A7 & 0.8 & 5.8 & & $1.4 \pm 0.1$ & $-0.03 \pm 0.1$ & $3.8 \pm 0.1$ & $-1.7 \pm 0.2$ \\
A3-A8 & 1.7 & 4.0 & & $1.4 \pm 0.1$ & $-0.1 \pm 0.1$ & $4.7 \pm 0.1$ & $-0.4 \pm 0.1$ \\
A4-A7 & 1.3 & 7.4 & & $1.4 \pm 0.1$ & $0.02 \pm 0.1$ & $3.7 \pm 0.1$ & $-0.8 \pm 0.1$ \\
A4-A8 & 2.7 & 5.0 & & $1.5 \pm 0.1$ & $-0.03 \pm 0.1$ & $4.2 \pm 0.1$ & $0.2 \pm 0.1$ \\
A4-A9 & 3.9 & 3.0 & & $1.6 \pm 0.2$ & $-0.1 \pm 0.1$ & $4.2 \pm 0.2$ & $1.3 \pm 0.2$ \\
A5-A7 & 2.3 & 10.1 & & $1.8 \pm 0.1$ & $-0.1 \pm 0.1$ & $3.6 \pm 0.1$ & $-0.6 \pm 0.1$ \\
A5-A8 & 3.8 & 6.0 & & $1.8 \pm 0.1$ & $-0.1 \pm 0.1$ & $4.5 \pm 0.1$ & $0.1 \pm 0.1$ \\
A5-A9 & 4.6 & 3.9 & & $1.7 \pm 0.1$ & $-0.1 \pm 0.1$ & $5.0 \pm 0.1$ & $0.3 \pm 0.1$ \\
A6-A7 & 3.2 & 12.5 & & $1.7 \pm 0.1$ & $-0.1 \pm 0.1$ & $3.3 \pm 0.1$ & $0.2 \pm 0.2$ \\
A6-A8 & 4.5 & 6.7 & & $1.7 \pm 0.1$ & $-0.1 \pm 0.1$ & $3.9 \pm 0.1$ & $0.7 \pm 0.1$ \\
A6-A9 & 5.0 & 4.3 & & $1.5 \pm 0.1$ & $-0.03 \pm 0.1$ & $4.4 \pm 0.1$ & $1.0 \pm 0.1$ \\
Average & 2.3 & 5.3 & & 1.5 & -0.1 & 4.1 & -0.8 \\
\hline
\end{tabular}

\begin{tabular}{|c|c|c|c|c|c|c|}
\hline \multirow[t]{2}{*}{ Diffusion couple } & \multicolumn{2}{|c|}{ Composition, at. $\%$} & \multicolumn{4}{|c|}{ Interdiffusion coefficients $\left(10^{-13} \mathrm{~m}^{2} \mathrm{~s}^{-1}\right)$} \\
\hline & $\mathrm{Al}$ & $\mathrm{Zr}$ & $\tilde{D}_{A l A l}^{T i}$ & $\tilde{D}_{A l Z r}^{T i}$ & $\tilde{D}_{Z r Z r}^{T i}$ & $\tilde{D}_{Z r A l}^{T i}$ \\
\hline B1-B9 & 0.4 & 3.2 & $6.2 \pm 0.3$ & $0.3 \pm 0.2$ & $16.8 \pm 0.2$ & $-1.6 \pm 0.9$ \\
\hline B1-B10 & 0.9 & 2.6 & $6.3 \pm 0.1$ & $-0.2 \pm 0.1$ & $14.3 \pm 0.1$ & $-2.2 \pm 0.1$ \\
\hline B1-B11 & 1.5 & 1.9 & $6.3 \pm 0.1$ & $-1.2 \pm 0.2$ & $16.7 \pm 0.1$ & $-1.9 \pm 0.1$ \\
\hline B2-B9 & 0.5 & 3.5 & $6.2 \pm 0.2$ & $0.3 \pm 0.2$ & $16.6 \pm 0.3$ & $-0.3 \pm 0.5$ \\
\hline B2-B10 & 1.2 & 2.9 & $6.7 \pm 0.1$ & $-0.2 \pm 0.1$ & $14.3 \pm 0.2$ & $-2.1 \pm 0.2$ \\
\hline B2-B11 & 2.2 & 2.4 & $6.9 \pm 0.1$ & $-1.1 \pm 0.1$ & $16.6 \pm 0.5$ & $-1.8 \pm 0.3$ \\
\hline B3-B9 & 1.2 & 5.9 & $9.0 \pm 0.1$ & $0.1 \pm 0.1$ & $17.6 \pm 0.2$ & $-0.9 \pm 0.5$ \\
\hline B3-B10 & 2.4 & 4.5 & $8.7 \pm 0.1$ & $-1.1 \pm 0.1$ & $16.3 \pm 0.1$ & $-3.5 \pm 0.1$ \\
\hline B3-B11 & 3.5 & 3.2 & $8.8 \pm 0.1$ & $-1.9 \pm 0.1$ & $18.0 \pm 0.2$ & $-2.7 \pm 0.7$ \\
\hline B4-B9 & 2.3 & 8.8 & $11.2 \pm 0.1$ & $0.5 \pm 0.1$ & $16.8 \pm 0.1$ & $2.8 \pm 0.2$ \\
\hline B4-B10 & 4.1 & 6.6 & $10.5 \pm 0.1$ & $-0.9 \pm 0.1$ & $16.2 \pm 0.2$ & $-2.1 \pm 0.2$ \\
\hline B4-B11 & 5.9 & 4.7 & $10.5 \pm 0.1$ & $-1.6 \pm 0.1$ & $18.4 \pm 0.1$ & $-1.6 \pm 0.1$ \\
\hline B5-B9 & 4.0 & 13.8 & $14.4 \pm 0.1$ & $0.2 \pm 0.1$ & $18.6 \pm 0.3$ & $1.4 \pm 0.9$ \\
\hline B5-B10 & 7.0 & 10.1 & $14.2 \pm 0.1$ & $-1.9 \pm 0.1$ & $18.5 \pm 0.4$ & $-3.3 \pm 0.4$ \\
\hline B5-B11 & 9.7 & 6.7 & $13.2 \pm 0.1$ & $-4.1 \pm 0.1$ & $20.2 \pm 0.6$ & $-2.1 \pm 0.5$ \\
\hline B6-B9 & 5.9 & 20.4 & $19.7 \pm 0.1$ & $-0.1 \pm 0.1$ & $20.5 \pm 0.3$ & $-1.7 \pm 0.3$ \\
\hline B6-B10 & 10.0 & 14.6 & $19.1 \pm 0.5$ & $-3.0 \pm 0.3$ & $20.1 \pm 0.2$ & $-4.5 \pm 0.3$ \\
\hline B6-B11 & 13.0 & 9.8 & $16.1 \pm 0.1$ & $-6.5 \pm 0.1$ & $19.8 \pm 0.4$ & $-6.2 \pm 0.7$ \\
\hline B7-B9 & 6.4 & 22.5 & $19.5 \pm 0.3$ & $0.3 \pm 0.1$ & $18.3 \pm 0.1$ & $8.1 \pm 0.4$ \\
\hline B7-B10 & 9.5 & 13.7 & $17.0 \pm 0.4$ & $-2.0 \pm 0.1$ & $18.3 \pm 0.4$ & $-3.0 \pm 1.0$ \\
\hline B7-B11 & 11.4 & 8.2 & $16.0 \pm 0.1$ & $-2.5 \pm 0.1$ & $18.0 \pm 0.1$ & $-5.2 \pm 0.3$ \\
\hline B8-B9 & 7.2 & 26.1 & $23.4 \pm 0.3$ & $-0.4 \pm 0.1$ & $20.6 \pm 0.2$ & $-2.8 \pm 0.5$ \\
\hline B8-B10 & 11.4 & 17.2 & $23.2 \pm 1.0$ & $-3.0 \pm 0.4$ & $19.2 \pm 0.6$ & $-7.6 \pm 1.4$ \\
\hline B8-B11 & 14.1 & 10.8 & $14.9 \pm 0.1$ & $-6.5 \pm 0.1$ & $18.3 \pm 0.7$ & $-7.8 \pm 1.6$ \\
\hline Average & 5.7 & 9.3 & 12.8 & -1.5 & 17.9 & -2.2 \\
\hline
\end{tabular}


Table 4 Impurity diffusion coefficients of $\mathrm{Al}$ in $\mathrm{Ti}-\mathrm{Zr}$ and $\mathrm{Zr}$ in Ti-Al binary Alloys

\begin{tabular}{|c|c|c|c|c|}
\hline Temperature & Composition & Impurity coefficients, $\mathrm{m}^{2} / \mathrm{s}$ & Composition & Impurity coefficients, $\mathrm{m}^{2} / \mathrm{s}$ \\
\hline \multirow[t]{6}{*}{$1273 \mathrm{~K}$} & $D_{\mathrm{A}(\mathrm{Ti}-4.4 \mathrm{Zr})}^{*}$ & $1.3 \times 10^{-13}$ & $D_{\mathrm{Zr}(\mathrm{Ti}-1.0 \mathrm{Al})}^{*}$ & $3.6 \times 10^{-13}$ \\
\hline & $D_{\mathrm{Al}(\mathrm{Ti}-9.9 \mathrm{Zr})}^{*}$ & $1.7 \times 10^{-13}$ & $D_{\mathrm{Zr}(\mathrm{Ti}-2.8 \mathrm{Al})}^{*}$ & $3.9 \times 10^{-13}$ \\
\hline & $D_{\mathrm{Al}(\mathrm{Ti}-13.5 \mathrm{Zr})}^{*}$ & $1.8 \times 10^{-13}$ & $D_{\mathrm{Zr}(\mathrm{Ti}-5.1 \mathrm{Al})}^{*}$ & $4.6 \times 10^{-13}$ \\
\hline & $D_{\mathrm{Al}(\mathrm{Ti}-19.9 \mathrm{Zr})}^{*}$ & $1.9 \times 10^{-13}$ & $D_{\mathrm{Zr}(\mathrm{Ti}-5.5 \mathrm{Al})}^{*}$ & $5.1 \times 10^{-13}$ \\
\hline & $D_{\mathrm{Al}(\mathrm{Ti}-28.2 \mathrm{Zr})}^{*}$ & $1.9 \times 10^{-13}$ & & \\
\hline & $\overline{D_{\mathrm{Al}(\mathrm{Ti}-\mathrm{Zr})}^{*}}$ & $1.7 \times 10^{-13}$ & $\overline{D_{\mathrm{Zr}(\mathrm{Ti}-\mathrm{Al})}^{*}}$ & $4.3 \times 10^{-13}$ \\
\hline \multirow[t]{7}{*}{$1473 \mathrm{~K}$} & $D_{\mathrm{A}(\mathrm{Ti}-4.3 \mathrm{Zr})}^{*}$ & $6.8 \times 10^{-13}$ & $D_{\mathrm{Zr}(\mathrm{Ti}-2.6 \mathrm{Al})}^{*}$ & $16.1 \times 10^{-13}$ \\
\hline & $D_{\mathrm{A}(\mathrm{Ti}-8.7 \mathrm{Zr})}^{*}$ & $11.5 \times 10^{-13}$ & $D_{\mathrm{Z}(\mathrm{Ti}-5.2 \mathrm{Al})}^{*}$ & $16.3 \times 10^{-13}$ \\
\hline & $D_{\mathrm{Al}(\mathrm{Ti}-12.9 \mathrm{Zr})}^{*}$ & $11.9 \times 10^{-13}$ & $D_{\mathrm{Zr}(\mathrm{Ti}-8.8 \mathrm{Al})}^{*}$ & $17.2 \times 10^{-13}$ \\
\hline & $D_{\mathrm{Al}(\mathrm{Ti}-19.9 \mathrm{Zr})}^{*}$ & $15.7 \times 10^{-13}$ & $D_{\mathrm{Zr}(\mathrm{Ti}-14.2 \mathrm{Al})}^{*}$ & $18.5 \times 10^{-13}$ \\
\hline & $D_{\mathrm{Al}(\mathrm{Ti}-28.7 \mathrm{Zr})}^{*}$ & $15.9 \times 10^{-13}$ & $D_{\mathrm{Zr}(\mathrm{Ti}-19.5 \mathrm{Al})}^{*}$ & $21.5 \times 10^{-13}$ \\
\hline & $D_{\mathrm{Al}(\mathrm{Ti}-38.4 \mathrm{Zr})}^{*}$ & $19.9 \times 10^{-13}$ & & \\
\hline & $\overline{D_{\mathrm{Al}(\mathrm{Ti}-\mathrm{Zr})}^{*}}$ & $13.6 \times 10^{-13}$ & $\overline{D_{\mathrm{Zr}(\mathrm{Ti}-\mathrm{Al})}^{*}}$ & $17.9 \times 10^{-13}$ \\
\hline
\end{tabular}
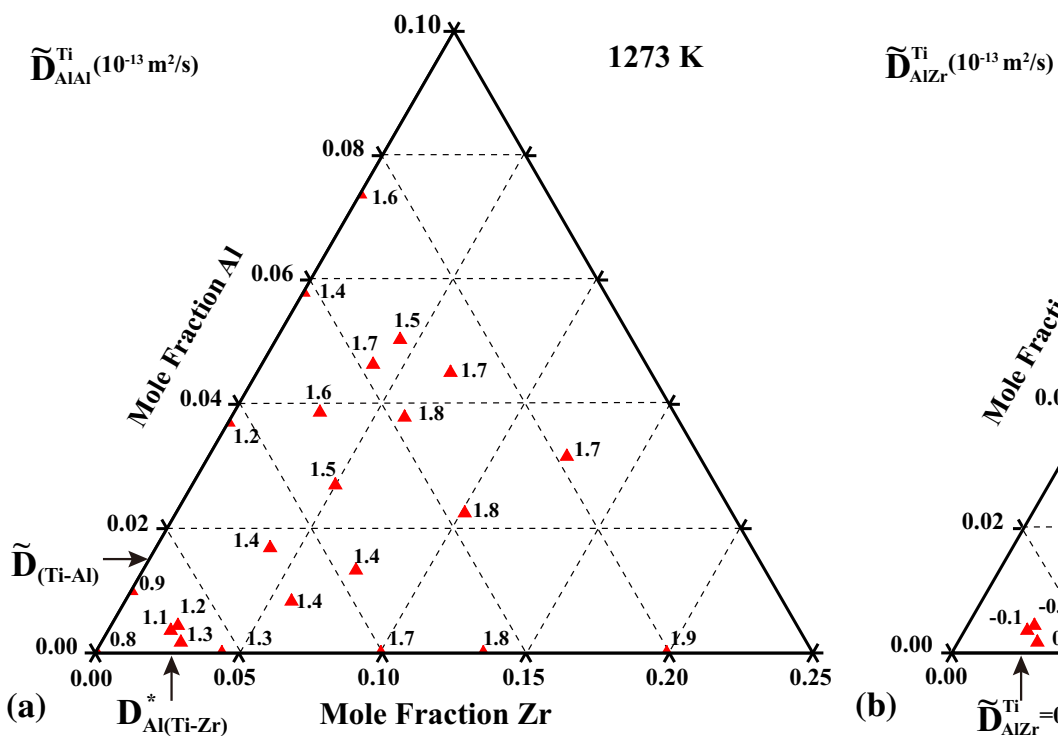

$1273 \mathrm{~K}$

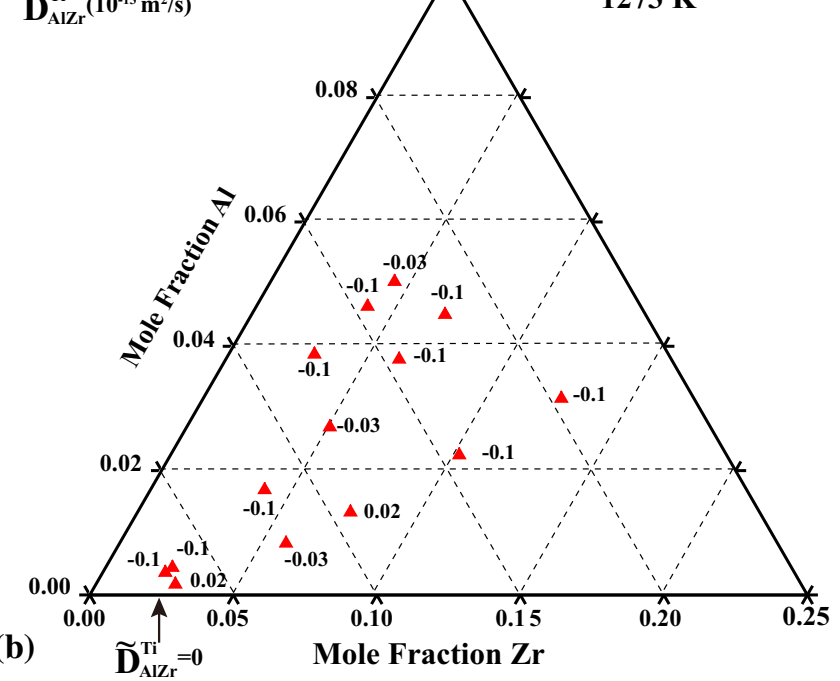

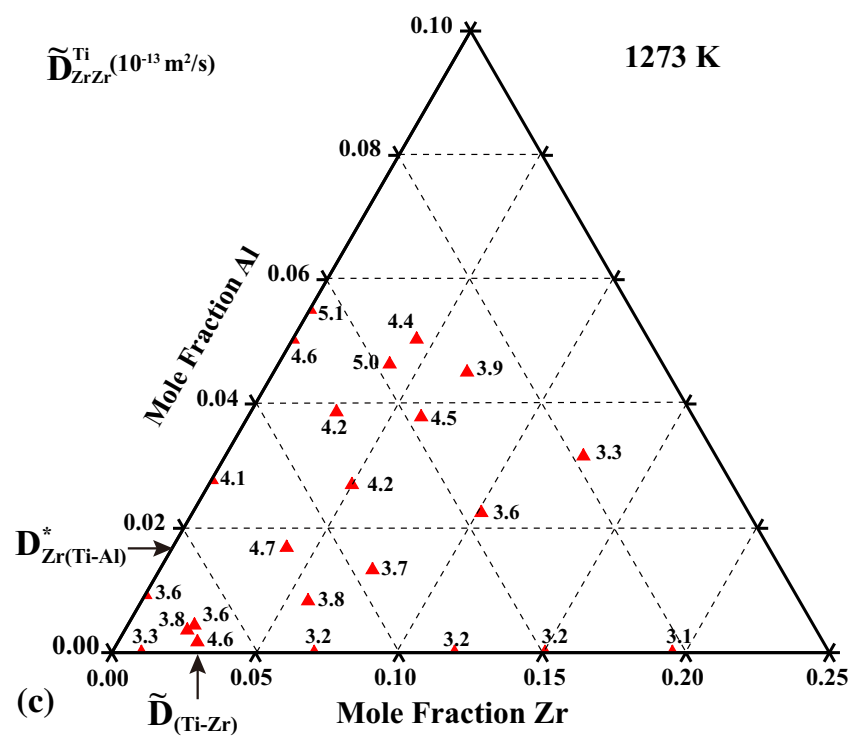

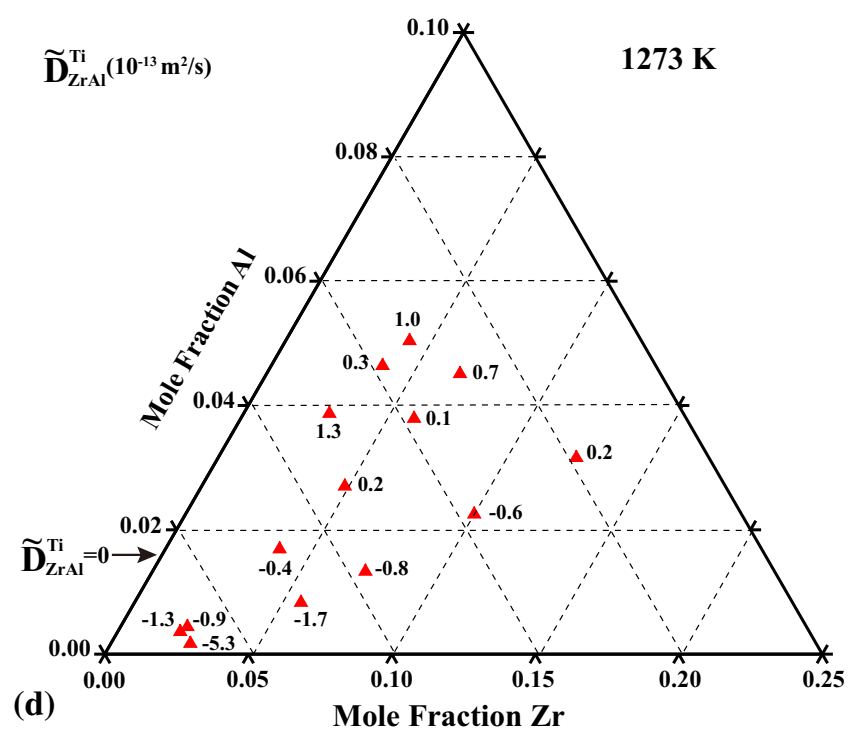

Fig. 4 Main and cross interdiffusion coefficients in BCC Ti-Al-Zr ternary alloys at $1273 \mathrm{~K}$, (a) $\tilde{D}_{\mathrm{AlAl}}^{\mathrm{Ti}}$, (b) $\tilde{D}_{\mathrm{AlZr}}^{\mathrm{Ti}}$, (c) $\tilde{D}_{\mathrm{ZrZr}}^{\mathrm{Ti}}$, and (d) $\tilde{D}_{\mathrm{ZrAl}}^{\mathrm{Ti}}$ 
validated by checking if the thermodynamic constraints derived by Kirkaldy ${ }^{[26]}$ are satisfied, i.e.

$\tilde{D}_{A l A l}^{T i}+\tilde{D}_{Z r Z r}^{T i}>0$,

$\tilde{D}_{A l A l}^{T i} \tilde{D}_{Z r Z r}^{T i}-\tilde{D}_{A l Z r}^{T i} \tilde{D}_{Z r A l}^{T i} \geq 0$,

$\left(\tilde{D}_{A l A l}^{T i}+\tilde{D}_{Z r Z r}^{T i}\right)^{2} \geq 4\left(\tilde{D}_{A l A l}^{T i} \tilde{D}_{Z r Z r}^{T i}-\tilde{D}_{A l Z r}^{T i} \tilde{D}_{Z r A l}^{T i}\right)$.

As shown in Tables 2 and 3, the main interdiffusion coefficients $\tilde{D}_{\mathrm{AlAl}}^{\mathrm{Ti}}$ and $\tilde{D}_{\mathrm{ZrZr}}^{\mathrm{Ti}}$ are much larger than the cross coefficients $\tilde{D}_{\mathrm{AlZr}}^{\mathrm{Ti}}$ and $\tilde{D}_{\mathrm{ZrAl}}^{\mathrm{Ti}}$ (approximately 8 and 9 times, respectively). As usual, the cross coefficients exhibit some scattering, and are believed to have low accuracy because of the inherent error when solving Fick's second law to extract the interdiffusion coefficients. At $1273 \mathrm{~K}$ $\left(1000{ }^{\circ} \mathrm{C}\right), \quad \tilde{D}_{\text {AlAl }}^{\mathrm{Ti}}$ ranges from $1.1 \times 10^{-13} \mathrm{~m}^{2} / \mathrm{s}$ to

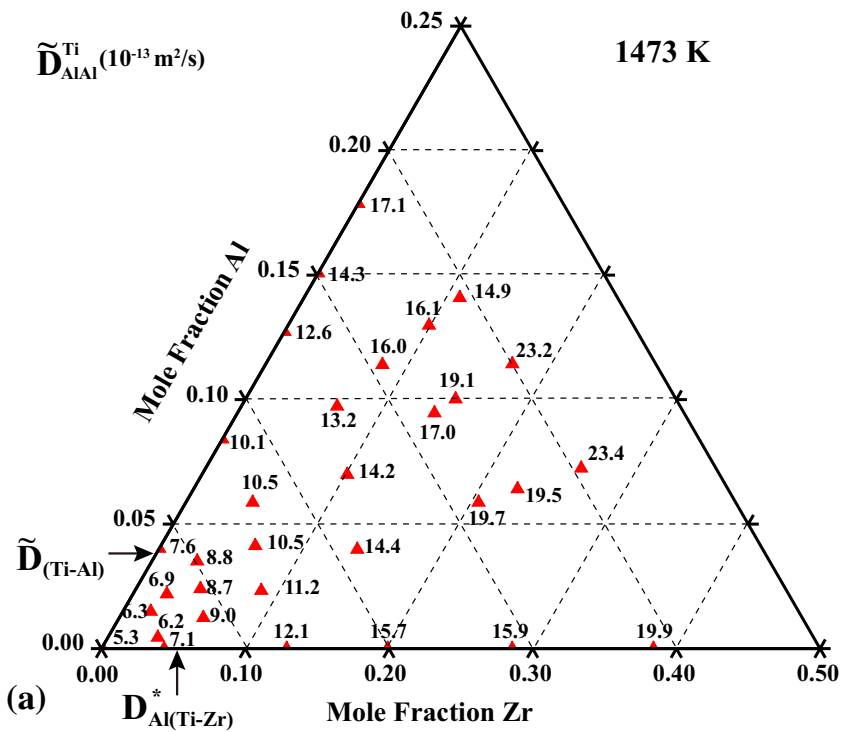

(a)

$$
\mathbf{D}_{\mathrm{Al}(\mathrm{Ti}-\mathrm{Zr})}^{*}
$$

Mole Fraction Zr

$1473 \mathrm{~K}$

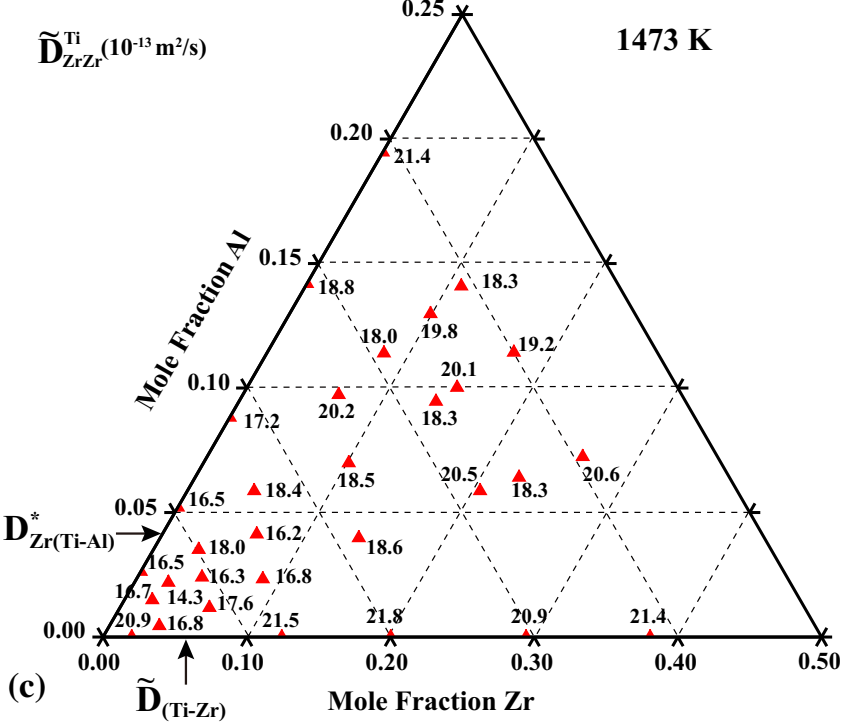

$1.8 \times 10^{-13} \mathrm{~m}^{2} / \mathrm{s}$ with the average value being $1.5 \times 10^{-13} \mathrm{~m}^{2} / \mathrm{s}$, whereas the average of $\tilde{D}_{\mathrm{ZrZr}}^{\mathrm{Ti}}$ is $4.1 \times 10^{-13} \mathrm{~m}^{2} / \mathrm{s}$, confirming the above-stated finding that $\mathrm{Zr}$ indeed diffuses faster than Al. It is also apparent that both $\tilde{D}_{\mathrm{AlAl}}^{\mathrm{Ti}}$ and $\tilde{D}_{\mathrm{ZrZr}}^{\mathrm{Ti}}$ have a weak compositional dependence. On contrast, the average value of $\tilde{D}_{\text {AlAl }}^{\mathrm{Ti}}$ is $12.8 \times 10^{-13} \mathrm{~m}^{2} / \mathrm{s}$ versus $19.8 \times 10^{-13} \mathrm{~m}^{2} / \mathrm{s}$ of $\tilde{D}_{\mathrm{ZrZr}}^{\mathrm{Ti}}$ at $1473 \mathrm{~K}\left(1200{ }^{\circ} \mathrm{C}\right)$, proving that the difference of diffusion rate between $\mathrm{Al}$ and $\mathrm{Zr}$ becomes smaller and is no longer three times. This is largely because $\tilde{D}_{\mathrm{AlAl}}^{\mathrm{Ti}}$ strongly increase with increasing the $\mathrm{Zr}$ content at higher temperature.

The impurity diffusion coefficients of $\mathrm{Zr}$ in binary Ti-Al alloys $D_{\mathrm{Zr}(\mathrm{Ti}-\mathrm{Al})}^{*}$ and of $\mathrm{Al}$ in Ti-Zr alloys $D_{\mathrm{Al}(\mathrm{Ti}-\mathrm{Zr})}^{*}$ were extracted from the A1-A6 and B1-B8 couples by generalized Hall method, respectively. The values listed in Table 4

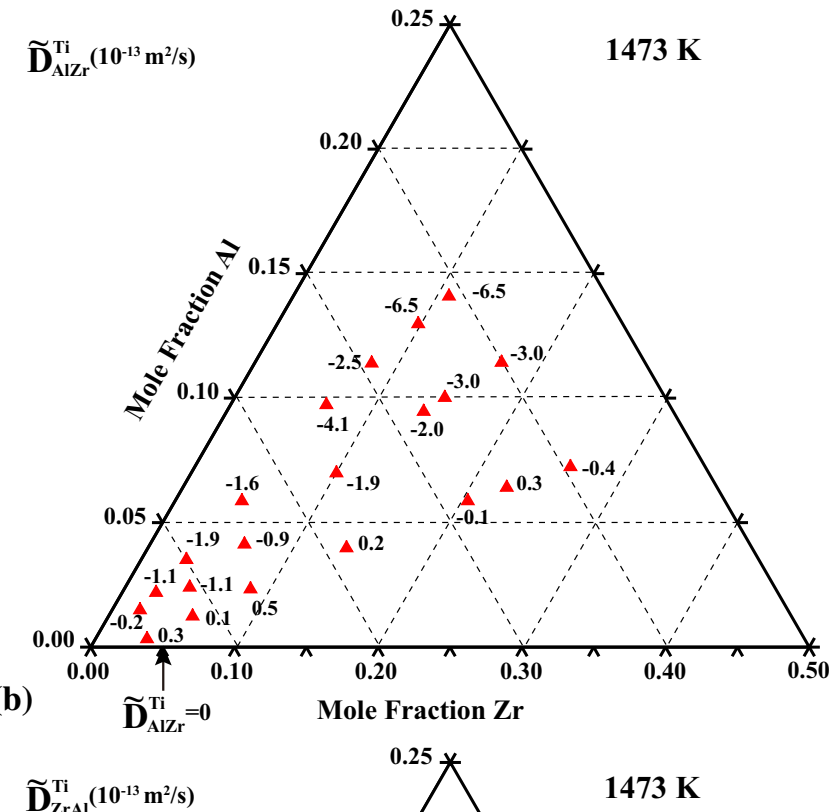

(d)

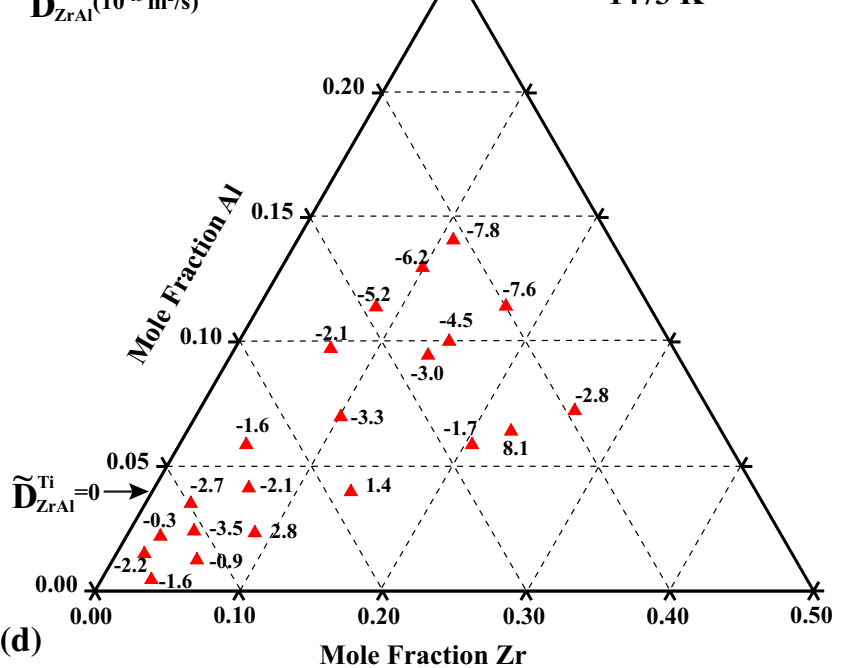

Fig. 5 Main and cross interdiffusion coefficients in BCC Ti-Al-Zr ternary alloys at $1473 \mathrm{~K}$, (a) $\tilde{D}_{\mathrm{AlAl}}^{\mathrm{Ti}}$, (b) $\tilde{D}_{\mathrm{AlZr}}^{\mathrm{Ti}}$, (c) $\tilde{D}_{\mathrm{ZrZr}}^{\mathrm{Ti}}$, and (d) $\tilde{D}_{\mathrm{ZrAl}}^{\mathrm{Ti}}$ 
depict that both $D_{\mathrm{Al}(\mathrm{Ti}-\mathrm{Zr})}^{*}$ and $D_{\mathrm{Zr}(\mathrm{Ti}-\mathrm{Al})}^{*}$ increase with increasing the content of $\mathrm{Al}$ and $\mathrm{Zr}$, respectively.

\section{Discussions}

\subsection{Composition Dependence of Interdiffusion Coefficients}

The extracted ternary interdiffusion coefficients are plotted in Fig. 4 for $1273 \mathrm{~K}\left(1000{ }^{\circ} \mathrm{C}\right)$ and Fig. 5 for $1473 \mathrm{~K}$ $\left(1200{ }^{\circ} \mathrm{C}\right)$, respectively. As pointed out by Shuck and Toor, ${ }^{[27]}$ the relation between the limit of the main diffusion coefficient $\tilde{\mathrm{D}}_{\mathrm{ii}}^{\mathrm{k}}$ in the i-k vicinity and binary interdiffusion coefficient $\tilde{\mathrm{D}}_{\mathrm{k}-\mathrm{i}}$ in the i-k binary is

$\lim _{\mathrm{x}_{\mathrm{j}} \rightarrow 0} \tilde{\mathrm{D}}_{\mathrm{ii}}^{\mathrm{k}}=\tilde{\mathrm{D}}_{\mathrm{k}-\mathrm{i}}$,

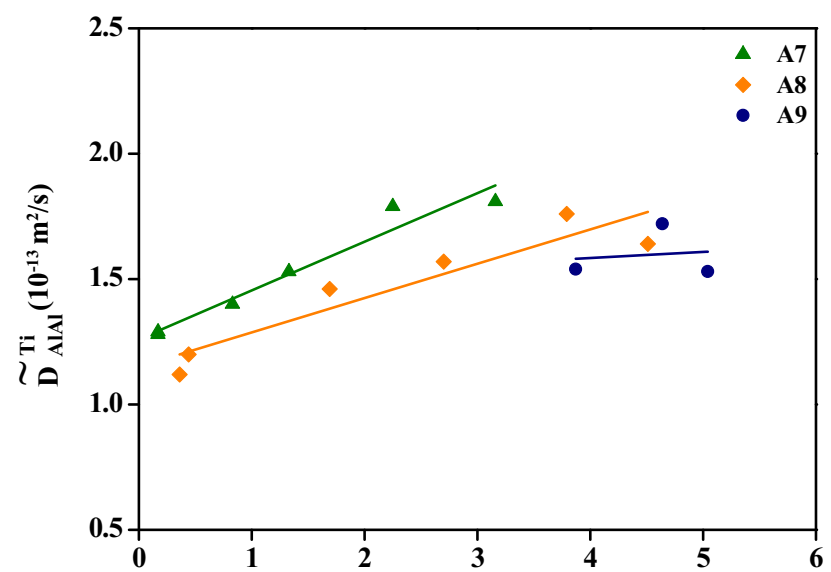

(a)

Al ( mole \%)

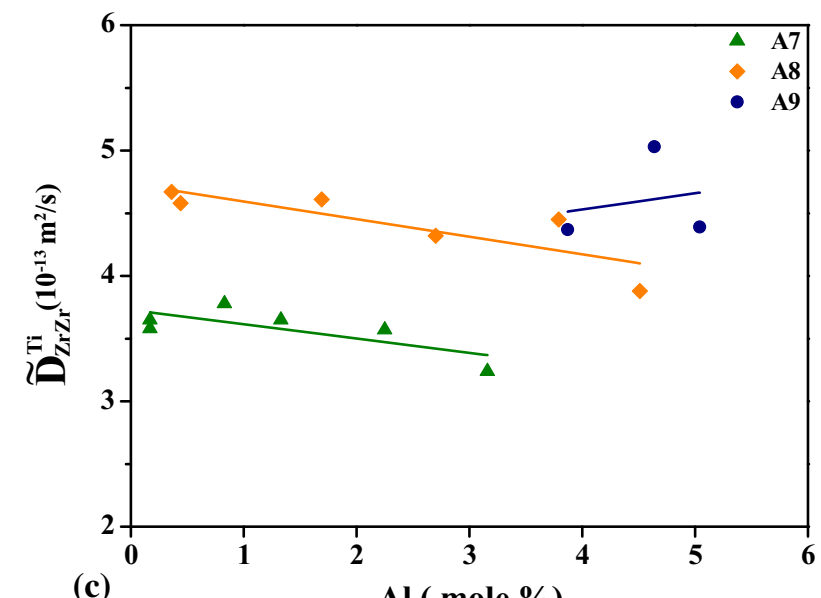

(c)

Al ( mole \%) and between the main diffusion coefficients $\tilde{\mathrm{D}}_{\mathrm{ii}}^{\mathrm{k}}$ in the $\mathrm{j}-\mathrm{k}$ vicinity and the impurity diffusion coefficients $\tilde{D}_{i(j-k)}^{*}$ in the j-k binary alloy, i.e.,

$\lim _{\mathrm{x}_{\mathrm{i}} \rightarrow 0} \tilde{\mathrm{D}}_{\mathrm{ii}}^{\mathrm{k}}=\mathrm{D}_{\mathrm{i}(\mathrm{j}-\mathrm{k})}^{*}$.

It therefore yields in the Ti-Al-Zr ternary that $\tilde{D}_{\text {AlAl }}^{\mathrm{Ti}}$ is degenerated to the binary $\mathrm{Ti}-\mathrm{Al}$ interdiffusion coefficient $\tilde{D}_{\mathrm{Ti}-\mathrm{Al}}$ as the $\mathrm{Zr}$ content approaches zero and to $\tilde{D}_{\mathrm{Al}(\mathrm{Ti}-\mathrm{Zr})}$ as $\mathrm{Al}$ goes to zero. Likewise, $\tilde{D}_{\mathrm{ZrZr}}^{\mathrm{Ti}}$ becomes $\tilde{D}_{\mathrm{Ti}-\mathrm{Zr}}$ and $\tilde{D}_{\mathrm{Zr}(\mathrm{Ti}-\mathrm{Al})}^{*}$ as $\mathrm{Al}$ and $\mathrm{Zr}$ approach to zero, respectively. Concerning the cross coefficients, it yields $\lim _{\mathrm{x}_{\mathrm{i}} \rightarrow 0} \tilde{D}_{\mathrm{ij}}^{\mathrm{k}}=0$ as the content of diffusing element is negligible. By additionally including the binary diffusion data of $\tilde{D}_{(\mathrm{Ti}-\mathrm{Al})}{ }^{[12,13,28]}$ and $\tilde{D}_{(\mathrm{Ti}-\mathrm{Zr})}{ }^{[14]}$ and the present impurity diffusion coefficients, it allows to map the broader composition dependence of the diffusion coefficients. A rough composition dependence could be thus outlined, for
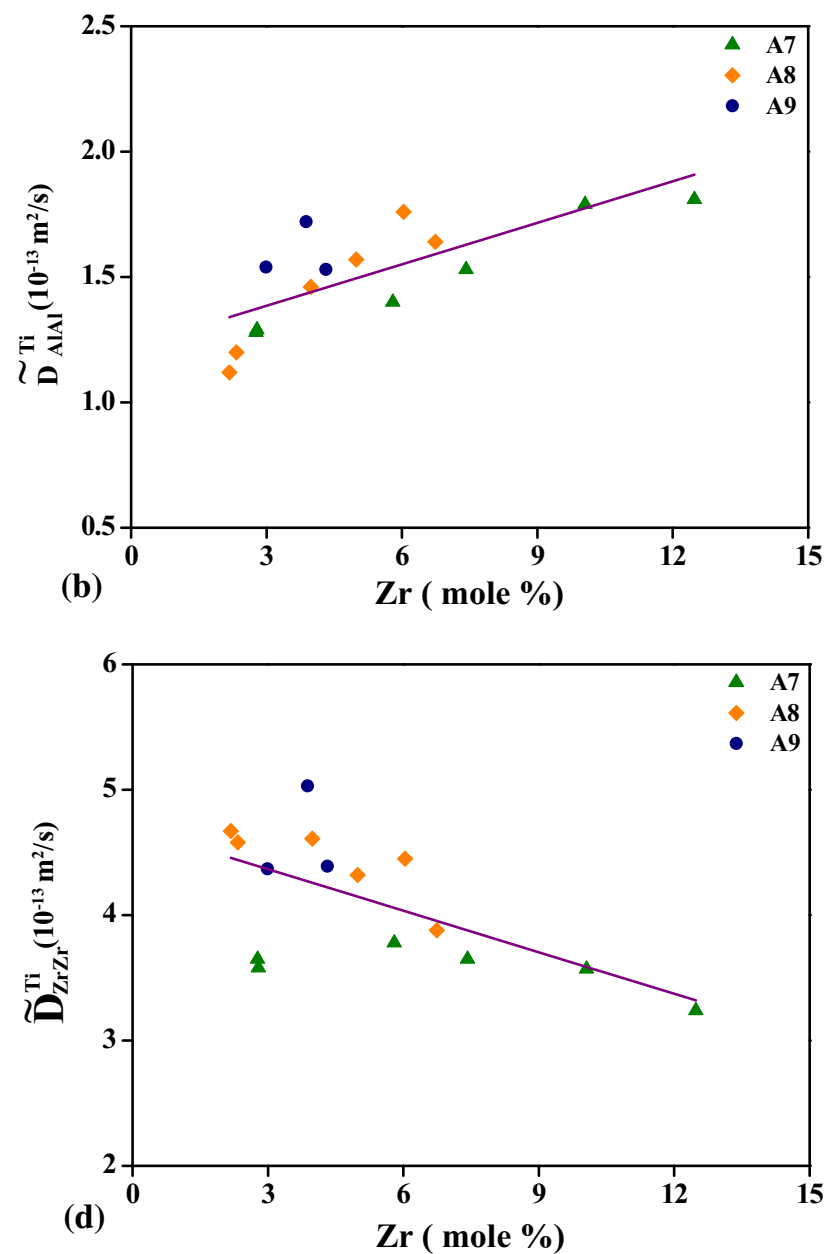

Fig. 6 The variation of ternary interdiffusion coefficients with the compositions at $1273 \mathrm{~K}$. (a) $\tilde{D}_{\mathrm{AlAl}}^{\mathrm{Ti}}$ with $\mathrm{Al}$; (b) $\tilde{D}_{\mathrm{AlAl}}^{\mathrm{Ti}}$ with $\mathrm{Zr}$; (c) $\tilde{D}_{\mathrm{ZrZr}}^{\mathrm{Ti}}$ with $\mathrm{Al}$; (d) $\tilde{D}_{\mathrm{ZrZr}}^{\mathrm{Ti}}$ with $\mathrm{Zr}$ 
specific, at $1273 \mathrm{~K}\left(1000{ }^{\circ} \mathrm{C}\right)$, the dependence of all four interdiffusion coefficients on the $\mathrm{Al}$ and $\mathrm{Zr}$ contents is weak and ambiguous. As for $1473 \mathrm{~K}\left(1200{ }^{\circ} \mathrm{C}\right)$, while the dependence of $\tilde{D}_{\mathrm{ZrZr}}^{\mathrm{Ti}}$ on the $\mathrm{Al}$ and $\mathrm{Zr}$ contents remains weak, $\tilde{D}_{\mathrm{AlAl}}^{\mathrm{Ti}}$ has strong dependence on the $\mathrm{Zr}$ content, i.e. significantly increases with adding $\mathrm{Zr}$.

The compositional dependence of all the interdiffusion coefficients could be quantified by illustrating the variation of the main interdiffusion coefficients $\tilde{D}_{\mathrm{AlAl}}^{\mathrm{Ti}}$ and $\tilde{D}_{\mathrm{ZrZr}}^{\mathrm{Ti}}$ with the compositions of $\mathrm{Al}$ and $\mathrm{Zr}$ at $1273 \mathrm{~K}\left(1000{ }^{\circ} \mathrm{C}\right)$ and $1473 \mathrm{~K}\left(1200{ }^{\circ} \mathrm{C}\right)$ in Fig. 6 and 7. It now becomes clearly that $\tilde{D}_{\mathrm{AlAl}}^{\mathrm{Ti}}$ increases with increasing the content of either $\mathrm{Al}$ or $\mathrm{Zr}$, and the increase appears more considerably at the higher temperature. However, $\tilde{D}_{\mathrm{ZrZr}}^{\mathrm{Ti}}$ was noticed to decrease with the increase of $\mathrm{Al}$ and $\mathrm{Zr}$ contents at $1273 \mathrm{~K}$ $\left(1000{ }^{\circ} \mathrm{C}\right)$ while presents an increasing trend at $1473 \mathrm{~K}$ $\left(1200{ }^{\circ} \mathrm{C}\right)$. These distinct variations of the main interdiffusion coefficients with respect to compositions are consistent with the interdiffusion in the BCC $\mathrm{Ti}^{-\mathrm{Zr}^{[14]}}$ and $\mathrm{Ti}$ -
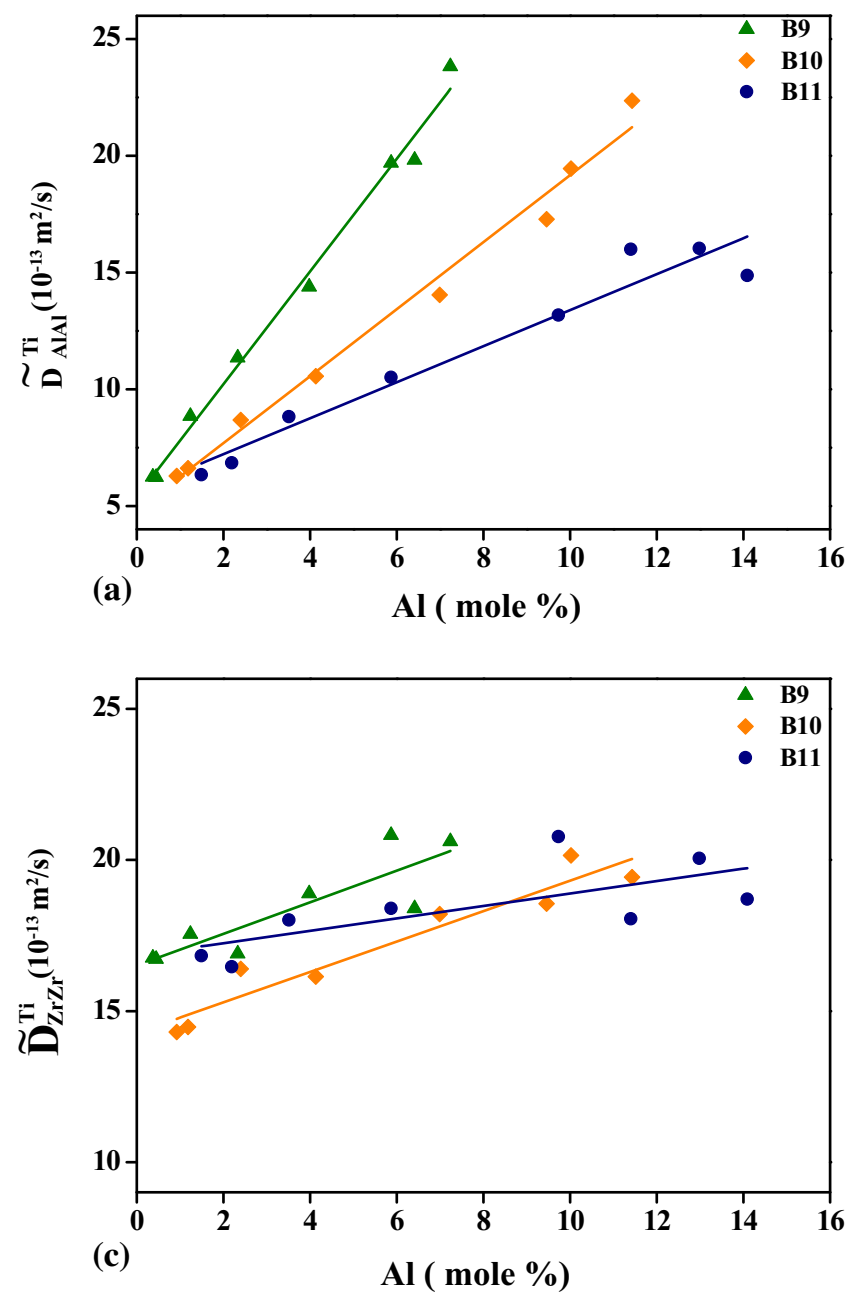

Mn binary alloys, ${ }^{[19]}$ which are very likely due to the thermodynamic contribution (via thermodynamic factor) varying with the composition in the ternary system to the interdiffusion coefficients.

\subsection{Temperature Dependence of Inter- and Impurity Diffusion Coefficients}

By comparing the average values of the main inter- and impurity diffusion coefficients, it yields $\overline{\tilde{D}_{\mathrm{AlAl}}^{\mathrm{Ti}}} / \tilde{\tilde{D}}_{\mathrm{ZrZr}}^{\mathrm{Ti}}(1273 K)=0.37, \overline{\tilde{D}_{\mathrm{AlAl}}^{\mathrm{Ti}}} / \tilde{\tilde{D}}_{\mathrm{ZrZr}}^{\mathrm{Ti}}(1473 K)=0.71$, $\overline{\tilde{D}_{\mathrm{Zr}(\mathrm{Ti}-\mathrm{Al})}^{*}} / \overline{\tilde{D}_{\mathrm{Al}(\mathrm{Ti}-\mathrm{Zr})}^{*}}(1273 K)=0.37, \frac{\tilde{\bar{D}}_{\mathrm{Zr}(\mathrm{Ti}-\mathrm{Al})}^{*}}{\overline{\bar{D}}_{\mathrm{Al}(\mathrm{Ti}-\mathrm{Zr})}(1473 K)}=0.66$. In addition, the average values of diffusion coefficients at $1273 \mathrm{~K}\left(1000{ }^{\circ} \mathrm{C}\right)$ and $1473 \mathrm{~K}\left(1200{ }^{\circ} \mathrm{C}\right)$ were also compared as follows, $\overline{\tilde{D}_{\mathrm{AlAl}}^{\mathrm{Ti}}}(1473 K) /{\tilde{\tilde{D}_{\mathrm{AlAL}}^{\mathrm{Ti}}}}^{\mathrm{Ti}}(1273 K)=8.50$, $\overline{\tilde{D}_{\mathrm{ZrZr}}^{\mathrm{Ti}}}(1473 K) /{\tilde{\tilde{D}_{\mathrm{ZrZr}}} \mathrm{Ti}}_{(1273 K)}=4.36, \overline{D_{\mathrm{Al}(\mathrm{Ti}-\mathrm{Zr})}^{*}}(1473 K) /$ $\overline{D_{\mathrm{Al}(\mathrm{Ti}-\mathrm{Zr})}^{*}}(1273 K)=7.06, \quad \overline{D_{\mathrm{Zr}(\mathrm{Ti}-\mathrm{Al})}^{*}}(1473 K) / \overline{D_{\mathrm{Zr}(}}$
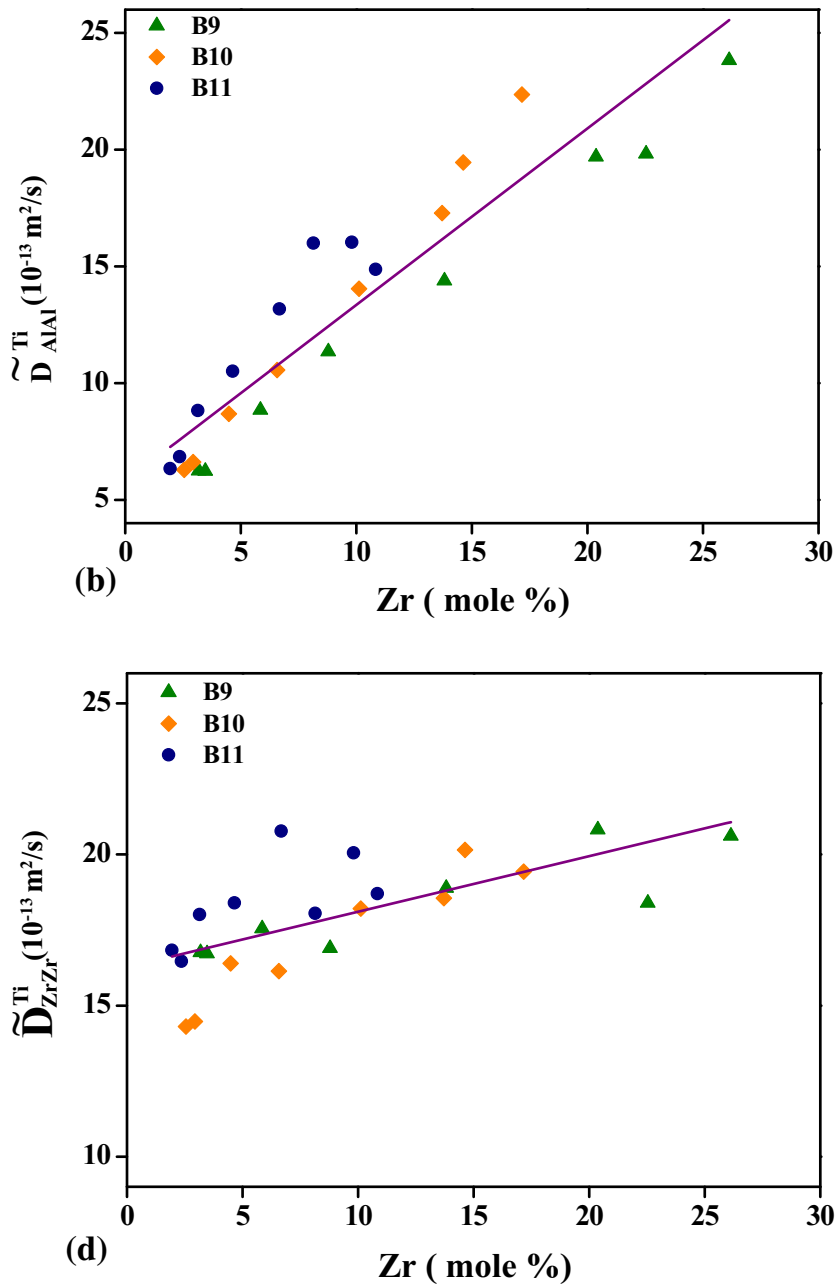

Fig. 7 The variation of ternary interdiffusion coefficients with the compositions at $1473 \mathrm{~K}$. (a) $\tilde{D}_{\mathrm{AlAl}}^{\mathrm{Ti}}$ with $\mathrm{Al}$; (b) $\tilde{D}_{\mathrm{AlAl}}^{\mathrm{Ti}}$ with $\mathrm{Zr}$; (c) $\tilde{D}_{\mathrm{ZrZr}}^{\mathrm{Ti}}$ with $\mathrm{Al}$; (d) $\tilde{D}_{\mathrm{ZrZr}}^{\mathrm{Ti}}$ with $\mathrm{Zr}$ 
Table 5 Average main interdiffusion coefficients in Ti-Al-X ternary systems (Ni, Co, Fe, Mn, Zr, Cr, Sn, V, Nb, and Mo) at $1473 \mathrm{~K}$

\begin{tabular}{lcc}
\hline & Average $\tilde{D}_{\text {AlAl }}^{\mathrm{Ti}}, \mathrm{m}^{2} / \mathrm{s}$ & Average $\tilde{D}_{\mathrm{XX}}^{\mathrm{Ti}}, \mathrm{m}^{2} / \mathrm{s}$ \\
\hline Ti-Al-Ni & $1.9 \times 10^{-12}$ & $2.2 \times 10^{-11}$ \\
Ti-Al-Co & $1.3 \times 10^{-12}$ & $1.9 \times 10^{-11}$ \\
Ti-Al-Fe & $1.3 \times 10^{-12}$ & $1.2 \times 10^{-11}$ \\
Ti-Al-Mn & $1.3 \times 10^{-12}$ & $3.1 \times 10^{-12}$ \\
Ti-Al-Zr & $1.3 \times 10^{-12}$ & $1.8 \times 10^{-12}$ \\
Ti-Al-Cr & $7.4 \times 10^{-13}$ & $1.6 \times 10^{-12}$ \\
Ti-Al-Sn & $9.2 \times 10^{-13}$ & $8.2 \times 10^{-13}$ \\
Ti-Al-V & $6.8 \times 10^{-13}$ & $4.1 \times 10^{-13}$ \\
Ti-Al-Nb & $6.2 \times 10^{-13}$ & $4.0 \times 10^{-13}$ \\
Ti-Al-Mo & $4.5 \times 10^{-13}$ & $1.5 \times 10^{-13}$ \\
\hline
\end{tabular}

$\mathrm{Ti}-\mathrm{Al})^{*}(1273 K)=4.02$. The findings obviously clarify that the temperature dependence is noticeable.

\subsection{Ti-Al-X Ternaries}

A systematic comparison of the average main interdiffusion coefficients at $1473 \mathrm{~K}\left(1200{ }^{\circ} \mathrm{C}\right)$ in ten Ti-Al-X $\left(\mathrm{Ni},{ }^{[29]} \mathrm{Co},{ }^{[30]} \mathrm{Fe},{ }^{[31]} \mathrm{Mn},{ }^{[19]} \mathrm{Zr}, \mathrm{Cr}^{[32]} \mathrm{Sn}^{[18]} \mathrm{V},{ }^{[33]}\right.$ $\mathrm{Nb},{ }^{[27]} \mathrm{Mo}^{[24]}$ ) ternary systems is presented in Table 5 . The diffusion rate of $\mathrm{Zr}$ is one order of magnitude smaller than the fast diffusers (i.e. $\mathrm{Ni}, \mathrm{Co}$, and $\mathrm{Fe}$ ) and is one order magnitude greater than the refractory metals (i.e. $\mathrm{V}, \mathrm{Nb}$, and Mo). It reveals that the order of the average main interdiffusion coefficient $\overline{\tilde{D}_{\mathrm{XX}}^{\mathrm{Ti}}}$ could be expressed as $D_{\mathrm{Ni}-}$ $>D_{\mathrm{Co}}>D_{\mathrm{Fe}}>D_{\mathrm{Mn}}>D_{\mathrm{Zr}}>D_{\mathrm{Cr}}>D_{\mathrm{Sn}}>D_{\mathrm{V}}>D_{\mathrm{Nb}-}$ $>D_{\mathrm{Mo}}$, thus the $\mathrm{Zr}$ diffusion is comparable to that of $\mathrm{Cr}$. Previous reports demonstrated that the diffusion of $\mathrm{Ni}, \mathrm{Co}$, and $\mathrm{Fe}$ in BCC Ti alloys is of the interstitial nature or by a mixed vacancy-interstitial mechanism ${ }^{[18,31,34]}$ ). The $\mathrm{Zr}$ diffusion in the Ti-Al-X ternary should thus occur via a normal vacancy mechanism like $\mathrm{Cr}, \mathrm{Sn}, \mathrm{V}, \mathrm{Nb}$, and $\mathrm{Mo}$, however, the $\mathrm{Al}$ diffusion is significantly promoted by the presence of $\mathrm{Zr}$.

\section{Conclusions}

In brief, diffusion behavior in BCC Ti-Al-Zr ternary alloys was investigated at $1273 \mathrm{~K}\left(1000{ }^{\circ} \mathrm{C}\right)$ and $1473 \mathrm{~K}$ $\left(1200{ }^{\circ} \mathrm{C}\right)$ by using the solid-state diffusion couple technique. The ternary inter- and impurity diffusion coefficients were extracted by the Whittle-Green and generalized Hall methods, respectively. The results are summarized as follows:

1. $\tilde{D}_{\mathrm{AlAl}}^{\mathrm{Ti}}$ increases with increasing the content of either $\mathrm{Al}$ or $\mathrm{Zr}$, and the increase is appearing more considerably at the higher temperature. However, $\tilde{D}_{\mathrm{ZrZr}}^{\mathrm{Ti}}$ was noticed to decrease with the increase of $\mathrm{Al}$ and $\mathrm{Zr}$ contents at $1273 \mathrm{~K}\left(1000{ }^{\circ} \mathrm{C}\right)$ while there is an upward trend at $1473 \mathrm{~K}\left(1200^{\circ} \mathrm{C}\right)$. Due to the relatively large scattering, the composition dependence of the cross interdiffusion coefficients is ambiguous.

2. The impurity diffusion coefficients $D_{\mathrm{Al}(\mathrm{Ti}-\mathrm{Zr})}^{*}$ and $D_{\mathrm{Zr}(\mathrm{Ti}-\mathrm{Al})}^{*}$ increase with increasing the content of alloying element at both $1273 \mathrm{~K}\left(1000{ }^{\circ} \mathrm{C}\right)$ and $1473 \mathrm{~K}\left(1200{ }^{\circ} \mathrm{C}\right)$.

3. A complete comparison of ten Ti-Al-X (Ni, Co, Fe, $\mathrm{Mn}, \mathrm{Zr}, \mathrm{Cr}, \mathrm{Sn}, \mathrm{V}, \mathrm{Nb}$, and $\mathrm{Mo}$ ) ternary systems was made with the average main interdiffusion coefficient $\tilde{D}_{\mathrm{XX}}^{\mathrm{Ti}}$. It exhibits $D_{\mathrm{Ni}}>D_{\mathrm{Co}}>D_{\mathrm{Fe}}>D_{\mathrm{Mn}}>D_{\mathrm{Zr}}>$ $D_{\mathrm{Cr}}>D_{\mathrm{Sn}}>D_{\mathrm{V}}>D_{\mathrm{Nb}}>D_{\mathrm{Mo}}$, and the $\mathrm{Zr}$ diffusion is most comparable to $\mathrm{Cr}$, suggesting it is a vacancycontrolled mechanism.

Acknowledgments This research was funded by the Defense Industrial Technology Development Program of China [No. JCKY2018414C020]. YC acknowledges the support from the Natural Science Funds of China [Grant No. 51571113]. GX was funded by the Natural Science Funds of China [Grant No. 51701094] and the Natural Science Funds of Jiangsu Province [Grant No. BK20171014]. FF and YG would like to thank the support from the Synergetic Innovation Center for Advanced Materials, Jiangsu Collaborative Innovation Center for Advanced Inorganic Function Composites, Nanjing Tech University.

\section{References}

1. G. Lütjering and J.C. Williams, Titanium Based Intermetallics, Springer, Berlin, 2003

2. R.R. Boyer, Attributes, Characteristics, and Applications of Titanium and Its Alloys, JOM, 2010, 62(5), p 21-24

3. R.R. Boyer and R.D. Briggs, The Use of $\beta$ Titanium Alloys in the Aerospace Industry, J. Mater. Eng. Perform., 2005, 14(6), p 681685

4. J.H. Xiong, S.K. Li, F.Y. Gao, and J.X. Zhang, Microstructure and Mechanical Properties of Ti6321 Alloy Welded Joint by GTAW, Metall. Trans. A, 2015, 640, p 419-423

5. X. Zhang, H.C. Kou, J.S. Li, F.S. Zhang, and L. Zhou, Evolution of the Secondary $\alpha$ Phase Morphologies During Isothermal Heat Treatment in Ti-7333 Alloy, J. Alloys Compd., 2013, 577(2-3), p 516-522

6. Y.L. Wang, S.X. Hui, R. Liu, and W.J. Ye, Evaluation of dynamic performance and ballistic behavior of Ti-5Al-5Mo-5V3Cr-1Zr alloy, Trans. Nonferrous Met. Soc., 2015, 25(2), p 429436

7. H. Chang, E. Gautier, F. Bruneseaux, and L. Zhou, $\beta \rightarrow \alpha+\beta$ Isothermal Phase Transformation Kinetics in Ti-B19 Metastable Titanium Alloy, Rare Metal Mat. Eng., 2006, 35(11), p 1696-1699

8. G.J. Fan, X.P. Song, M.X. Quan, and Z.Q. Hu, Mechanical Alloying and Thermal Stability of Al $67 \mathrm{Ti} 25 \mathrm{M} 8(\mathrm{M}=\mathrm{Cr}, \mathrm{Zr}$, Cu), Metall. Trans. A, 1997, 231(1-2), p 111-116

9. L. Feng, J.S. Li, Y.W. Cui, L. Huang, H.C. Kou, and L. Zhou, Research on Interdiffusion Behavior of Ti-Zr Binary Alloy in the $\beta$ Phase, Rare Met. Mater. Eng., 2011, 40(04), p 610-614 
10. Q. Chen, N. Ma, K.S. Wu, and Y.Z. Wang, Quantitative Phase Field Modeling of Diffusion-Controlled Precipitate Growth and Dissolution in Ti-Al-V, Scr. Mater., 2004, 50(4), p 471-476

11. $\mathrm{H}$. $\mathrm{Hu}$ and S.A. Argyropoulos, Mathematical Modelling of Solidification and Melting: A Review, Model. Simul. Mater. Sci. Eng., 1996, 4, p 371-396

12. H. Araki, T. Yamane, Y. Minamino, S. Saji, Y. Hana, and S.B. Jung, Anomalous Diffusion of Aluminum in $\beta$-Titanium, Metall. Trans. A, 1994, 25(4), p 874-876

13. S.Y. Lee, O. Taguchi, and Y. Iijima, Diffusion of Alummum in $\beta$ Titanium, Mater. Trans., 2010, 51(10), p 1809-1813

14. I. Thibon, D. Ansel, and T. Gloriant, Interdiffusion in $\beta-\mathrm{Ti}-\mathrm{Zr}$ Binary Alloys, J. Alloys Compd., 2009, 470(1-2), p 127-133

15. F. Yang, F.H. Xiao, S.G. Liu, S.S. Dong, L.H. Huang, Q. Chen, G.M. Cai, H.S. Liu, and Z.P. Jin, Isothermal Section of Al-Ti-Zr Ternary System at $1273 \mathrm{~K}$, J. Alloys Compd., 2014, 585, p 325330

16. A.G. Nikitin, S.V. Spichak, S.V. Yu, and A.G. Naumovets, Symmetries and Modelling Functions for Diffusion Processes, $J$. Phys. D, 2009, 42, p 55301

17. W.M. Bai, Y.Y. Tian, G.L. Xu, Z.J. Yang, L.B. Liu, P.J. Masset, and L.G. Zhang, Diffusivities and Atomic Mobilities in bcc TiZr-Nb Alloys, Calphad, 2019, 62, p 160-174

18. Q.J. Wu, J.Y. Wang, Y.Y. Gu, Y.H. Guo, G.L. Xu, and Y.W. Cui, Experimental Diffusion Research on BCC Ti-Al-Sn Ternary Alloys, J. Phase Equilib. Diff., 2018, 39(5), p 724-730

19. X. Huang, Y.J. Tan, Y.H. Guo, G.L. Xu, and Y.W. Cui, Experimental Diffusion Research on BCC Ti-Mn Binary and Ti-Al-Mn Ternary Alloys, J. Phase Equilib. Diffus., 2018, 39(5), p 702-713

20. J.S. Kirkaldy, Diffusion in Multicomponent Metallic Systems, Can. J. Phys., 1957, 35(4), p 435-440

21. D.P. Whittle and A. Green, The Measurement of Diffusion Coefficients in Ternary Systems, Scr. Mater., 1974, 8(7), p 883884

22. C.Y. Wang, G.L. Xu, and Y.W. Cui, Mapping of Diffusion and Nanohardness Properties of Fcc Co-Al-V Alloys Using Ternary Diffusion Couples, Metall. Trans. A, 2017, 48(9), p 4286-4296

23. L.D. Hall, An Analytical Method of Calculating Variable Diffusion Coefficients, J. Chem. Phys., 1953, 21, p 87-89
24. Y. Chen, B. Tang, G.L. Xu, C.Y. Wang, H.C. Kou, J.S. Li, and Y.W. Cui, Diffusion Research in BCC Ti-Al-Mo Ternary Alloys, Metall. Mater. Trans. A, 2014, 45A(4), p 1647-1652

25. Y. Chen, J.S. Li, B. Tang, G.L. Xu, H.C. Kou, and Y.W. Cui, Interdiffusion in FCC Co-Al-Ti Ternary Alloys, J. Phase Equilib. Diff., 2015, 36(2), p 127-135

26. J.S. Kirkaldy, D. Weichert, and Z.U. Haq, Diffusion in Multicomponent Metallic Systems: VI. Some Thermodynamic Properties of the D Matrix and the Corresponding Solutions of the Diffusion Equations, Can. J. Phys., 1963, 41(12), p 2166-2173

27. F.O. Shuck and H.L. Toor, Diffusion in the Three Component Liquid System Methyl Alcohol-n-Propyl Alcohol-Isobutyl Alcohol, J. Phys. Chem., 1963, 67(3), p 540-545

28. Y.Y. Gu, F.J. Fan, Y.H. Guo, G.L. Xu, H. Chang, L. Zhou, and Y.W. Cui, Diffusion and Atomic Mobility of BCC Ti-Al-Nb Alloys: Experimental Determination and Computational Modeling, Calphad, 2018, 62, p 83-91

29. B. Gao, Y.Y. Gu, Q.J. Wu, Y.H. Guo, and Y.W. Cui, Diffusion Research in BCC Ti-Al-Ni Ternary Alloys, J. Phase Equilib. Diff., 2017, 38(4), p 502-508

30. T. Takahashi, Ternary Diffusion and Thermodynamic Interaction in the $\beta$ Solid Solutions of Ti-Al-Co Alloys, J. Jpn. Inst. Met., 2009, 59(8), p 432-438

31. T. Takahashi and Y. Minamino, Ternary Diffusion and Thermodynamic Interaction in the $\beta$ Solid Solutions of Ti-Al-Fe Alloys at 1423 K, J. Alloys Compd., 2012, 545, p 168-175

32. W.B. Li, B. Tang, Y.W. Cui, R. Hu, H. Chang, J.S. Li, and L. Zhou, Assessment of Diffusion Mobility for the bcc Phase of the Ti-Al-Cr System, Calphad, 2011, 35, p 384-390

33. L. Huang, Y.W. Cui, H. Chang, H. Zhong, J.S. Li, and L. Zhou, Assessment of Atomic Mobilities for bcc Phase of Ti-Al-V System, J. Phase Equilib. Diff., 2010, 31(2), p 135-143

34. G.M. Hood and R.J. Schultz, Ultra-fast Solute Diffusion in $\alpha-T i$ and $\alpha$-Zr, Philos. Mag., 1972, 26(2), p 329-336

Publisher's Note Springer Nature remains neutral with regard to jurisdictional claims in published maps and institutional affiliations. 